\title{
Enacting resilience for adaptive water governance: a case study of irrigation modernization in an Australian catchment
}

\author{
Margaret L. Ayre ${ }^{1}$ and Ruth A. Nettle ${ }^{1}$
}

\begin{abstract}
Adaptive governance relies on the collaboration of a diverse set of stakeholders in multiple institutions and organizations at different times and places. In the context of unprecedented water policy and management reform in Australia over the past decade, we add to insights from resilience scholarship, which identifies adaptive governance as critical to improving complex social-ecological systems, such as water management. We present empirical research with agricultural industry stakeholders who are responding to a major change initiative to renew or modernize the largest irrigation system in Australia's Murray Darling Basin and who ask: "What can a resilience assessment intervention contribute to adaptive water governance in this context?" Using resilience approaches and connecting these with insights from science and technology studies (STS), we found that a particular resilience assessment intervention supported dairy industry stakeholders to manage the complexity, uncertainty, and diversity of an irrigation modernization governance challenge. It did so by explicitly accounting for, representing, and aligning different water governing practices through the use of resilience concepts, a particular resilience assessment tool, and a participatory process for engaging social actors. Possibilities for adaptive governance emerged from the intervention in the form of new joint strategic actions and new understandings, alliances, and roles between people and institutions for addressing irrigation modernization.
\end{abstract}

Key Words: adaptive governance; collective action; irrigation modernization; resilience assessment

\section{INTRODUCTION}

Governments, communities, and industries around the world are increasingly faced with governing major change processes in complex social-ecological systems (SES), such as catchments and irrigation systems. Finding ways to improve outcomes for people and their organizations, as well as meeting environmental objectives of such change processes, will require governance approaches that address the inherent diversity (Mostert et al. 2008, Bell et al. 2011), complexity (Miller et al. 2010), and uncertainty (Lebel et al. 2006) of complex social-ecological systems. This includes disparate and contested types and scales of activity (Folke 2006), multiple knowledges (Enserink et al. 2007), and interests and objectives of communities along with incomplete knowledge and information related to SES dynamics (Fish et al. 2010, Ison et al. 2011, Pahl-Wostl et al. 2012). Although this diversity, complexity, and uncertainty are all well recognized attributes of SES (Orr et al. 2007, Pahl-Wostl 2007a, Head 2010), the challenge of effectively managing these attributes in ways that produce improved social-ecological outcomes for people and their places remains. However, any new approaches to SES governance for resources management must account for the range of socialecological values in SES, promote the equitable distribution of costs and benefits from resource use, and will need to engage the full range of stakeholders in decision making and implementation (Folke 2003, Olsson et al. 2004, Folke et al. 2005, Pahl-Wostl et al. 2007, Fish et al. 2010, Pahl-Wostl and Kranz 2010, Barnes and Alatout 2012, Daniell 2013, Ison et al. 2013).

Resilience scholars propose that the challenges of managing diversity, complexity, and uncertainty in SES can be met through the development of more inclusive processes and alternative or complementary governance models from government-driven ones (Ostrom 2007, Wallis et al. 2015). Adaptive governance is understood as one such alternative model, which is defined broadly as: governance approaches that are collaborative, flexible, and learning-based and rely on networks of people and organizations at multiple levels (Resilience Alliance 2010). The goal of adaptive governance is to manage change in complex SES so as to maintain the resilience (or enable transformation) of communities, their places, and institutions (Lebel et al. 2006). Adaptive governance as a concept and principle has been widely theorized in resilience approaches to understand and manage change in SES, including catchments and irrigation systems (Walker et al. 2004, Folke et al. 2005, Olsson et al. 2006, Smit and Wandel 2006, Pahl-Wost1 2007a, $b$, 2009). The important question of its policy relevance has also been examined (Nelson et al. 2008, Nettle and Paine 2009, Daniell 2013). However, scholars have identified the outstanding need to operationalize (Bahadur et al. 2010, Wardekker et al. 2010, Rickards and Howden 2012, Davidson et al. 2013) or enact (Wagenaar and Wilkinson 2013) resilience approaches to design and implement practical interventions for improving SES governance (Miller et al. 2010, Ison et al. 2011, Davidson et al. 2013, Sinclair et al. 2014).

We describe how a particular intervention enabled people and their institutions to better align their diverse governing practices for achieving shared outcomes. This intervention aimed to respond to a call for new governance approaches to better engage water users and managers in decisions about the future management of Australia's largest irrigation district, the Goulburn Murray Irrigation District (GMID) in the Murray Darling Basin (MDB; Fig. 1). The GMID has recently been identified as the irrigation district under the most impact by water policy reform measures as part of a MDB-wide water planning process (RMCG 2016), which came into effect in 2012. Issues faced by irrigated agricultural industries in this context are: new government requirements to upgrade irrigation infrastructure regionally and on-farm to improve water delivery and use efficiency; and, new water allocation systems including new water markets and complex new rules for water trading. 
Fig. 1. Map showing location of the Murray Darling Basin and the Goulburn Murray Irrigation District in Australia.

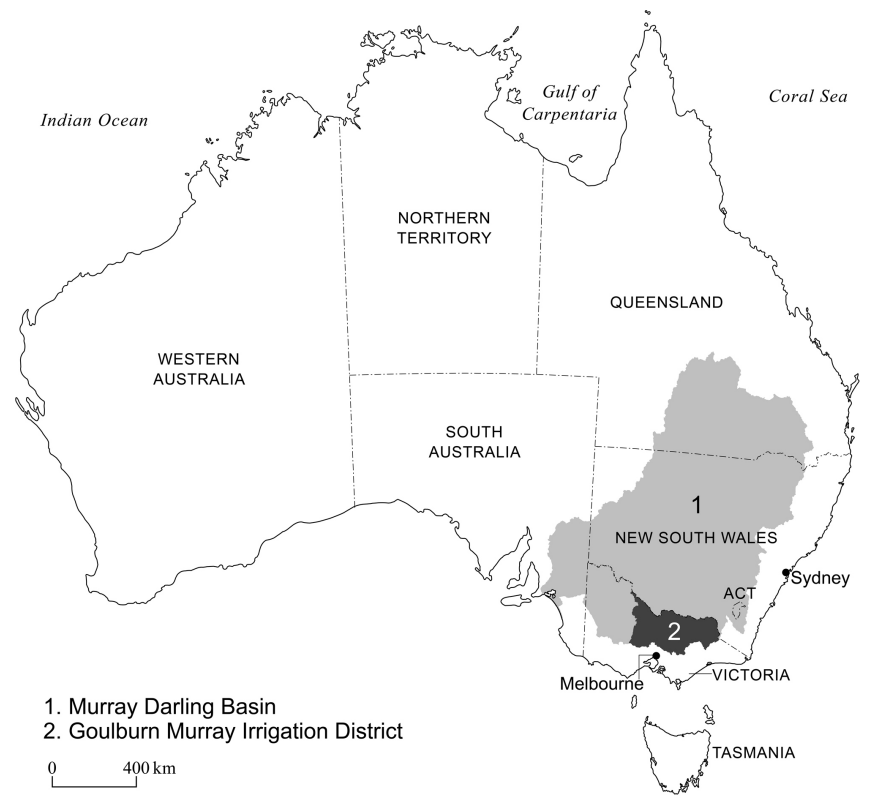

By intervention, we refer to a process whereby: “...theory is explicitly used to intervene to create collective action from which new insights can be drawn" (Daniell et al. 2010). The design of this intervention was based on some of the conceptual and practical elements of the Workbook for Assessing Resilience in Socio-ecological Systems (the RA workbook) developed by the Resilience Alliance (Walker et al. 2004). This workbook has been used to assess the resilience of complex systems in Australia (Walker et al. 2009, Mitchell 2013, Mitchell et al. 2014) and internationally (Haider et al. 2012, Sellberg et al. 2015) in the context of natural resource management.

In Australia and elsewhere, many attempts to govern major change processes in SES have failed to meet justice or sustainability criteria, including the recent initiative to renew or modernize the GMID. This initiative, known as the G-MW Connections Project (the Project), has generally been met with contestation and poor rates of adoption among stakeholders (Alston 2012, Collett and Henry 2014, Wallis et al. 2015). An independent midterm review of the Project in 2015 found that intended outcomes for irrigators have not been met, with the "... point made many times by irrigators that they were not listened to, or involved in, the plan [for irrigation modernization]" (GHD 2015:15). We provide an account of the everyday actions of governments, industry, and communities as they respond to the adaptive governance challenge of the Project and ask: what can a resilience assessment intervention contribute to adaptive water governance in this context? Our research adds to the current understanding on what supports adaptive governance and how it can be actively managed by industry, governments, and communities for improved outcomes for people and their places.

\section{Collective action for adaptive water governance}

Adaptive governance has been conceptualized in resilience approaches as a key component of adaptability (Walker et al. 2004) and includes "the set of actions undertaken to maintain the capacity to deal with current or future predicted change" (Nelson et al 2008:396). It also involves managing the cross-scale interactions between different systems dynamics and states at different scales in SES (Walker et al. 2004). Many resilience scholars identify adaptive governance as a process of learning in groups or social learning (Brown and Lambert 2012). In such learning situations, people participate in activities focused on deliberation and reflexivity toward ongoing negotiation and settlement of joint actions (Blackmore et al. 2007, Mostert et al. 2008, Pahl-Wostl et al. 2008, Anderies et al. 2013, Ison et al. 2015). Others, notably from institutional economics, have identified adaptive governance as a process of collective action (Ostrom 1990, 2005, Blomquist 1992, Ostrom and Gardner 1993, Olsson 2009) that characterizes settings in water management in particular, "...in which there is a group of individuals, a common interest among them, and potential conflict between the common interest and each individual's interest" (Ostrom and Anh 2008:5).

We take social learning and collective action to be the same process; however, we chose to focus on collective action because, although some resilience scholars have identified collective action as a key aspect of adaptive governance (Stoker 1998), the question of how to support collective action in practice has not been comprehensively addressed in the resilience literature.

Although there are various theories of collective action arising from a range of disciplinary perspectives, including institutional economics, feminist studies (Addelson 1994), innovation studies (Hargrave and Van de Ven 2006, Devaux et al. 2009, Hellin 2012), sociology (Rydin and Pennington 2000, Adger 2010) and political science (Stoker 1998), we seek to contribute to the understanding of what is required for collective action for adaptive governance using a perspective from science and technology studies (STS). This perspective adds to insights on operationalizing resilience theory related to collective action and adaptive governance. It does so by bringing together aspects of resilience theory and actor network theory (ANT; Law 1999, Latour 2005).

In an ANT approach to understanding collective action, all learning and change processes, such as adaptive governance, are constituted in and through sets of social, material, and symbolic practices (Shapin and Schaffer 1985, Latour 1987). As Shove and Walker (2010:475) noted: “...when practices change they do so as an emergent outcome of the actions and inactions of all (including materials and infrastructures, not just humans)." Hence, adaptive governance is achieved through mobilizing heterogeneous (Callon, 1986, Law 2012, Mol 2002) practices in the form of:

- symbols or representations, e.g., narrative (Paschen and Ison 2014) and discourse (Rickards et al. 2014);

- material resources, e.g., physical resources (Tyre and von Hippel 1997); and,

- social arrangements, e.g., people and their institutions.

Definitions of key concepts and terms referred to are provided in Table 1. We seek to contribute to the burgeoning body of research and practical possibilities arising from synergies between 
Table 1. Definitions of key concepts.

Knowledge practices: constitute different sets of social arrangements, materials and symbols, and representations. This definition draws from science and technology studies (STS) scholars, Shapin and Schaffer (1985) who proposed a typology of technologies of scientific knowledge. In this constructivist epistemology, scientific knowledge is generated or performed through the strategic coordination of social, material, and textual technologies. However, instead of technologies, we refer to knowledge practices to emphasize the embodied nature of doing the work of adaptive governance (see Ayre and Nettle 2015). In this framing (Schon 1984), all knowledge is understood as constituted or performed in everyday, collective action (Star and Greismer 1989, Gibbons et al. 1994, Mol and Law 1998, Latour 1999).

Heterogeneous refers to diverse knowledge practices in networks of social, material, and representational objects and actors. The metaphor of the heterogeneous network is a foundational concept in actor-networktheory and "....is a way of suggesting that society, organizations, agents and machines are all effects generated in patterned networks of diverse (not simply human) materials" (Law 1992:1).

Translation (or mobilization) is defined (following Callon and Law 1989:58-59) as "a process in which sets of relations between projects, interests, goals and naturally occurring entities-

objects which might otherwise be quite separate from one another-are proposed and brought into being."

Actor-network-theory (ANT) is a sociological approach to the study of knowledge production, which posits that "entities (e.g. objects and actors) take their form and acquire their attributes as a result of their relations with other entities" (Law 1992:3). Therefore, objects and actors are contingent on and emergent in the relations in networks of social, material, and symbolic knowledge practices.

Actors (in ANT approaches) are both human and nonhuman and are entities in a network that produce certain effects by virtue of their relations with other entities (see Callon and Law 1989, Latour 1999).

Institution refers to "a site and to laws, people and customs that continue in time" (Latour 1999:307). For example, organizations are a form of institution.

Adaptive governance may be broadly defined as governance approaches that are collaborative, flexible and learning-based and rely on networks of people and organizations at multiple levels (Resilience Alliance 2010).

Resilience may be broadly defined as: "...the capacity of a [socialecological] system to absorb disturbance and reorganize while undergoing change so as to still retain essentially the same function, structure, identity, and feedbacks" (Walker et al. 2004).

resilience theory and STS (Dwiartania and Rosin 2014, StoneJovicich 2015). Synergies between these two approaches to understanding change processes in SES in resilience approaches (Folke 2006) or actor networks (Callon 1986, Law 2004, Latour 2005) in STS approaches, hold promise, both as a guide to the content and design of governance interventions and for the analysis of collective action for adaptive governance.

\section{The G-MW connections project: a water governance challenge for the dairy industry}

Valuable insights into the governance of the irrigation modernization process in Australia's Murray Darling Basin have been made by others (Alston and Whittenbury 2011), including the change initiative that is the Project (see Collett and Henry 2014, Wallis et al. 2015). We add to these by focusing on a particular agricultural sector, the dairy industry, and its experiences of and responses to the Project in the Goulburn Murray Irrigation District (see Fig. 1). Although there has been substantive research that problematizes the role of the state in water governing (Carroll 2012, Cook et al. 2013), there has been less focus on the role of industry in governance efforts for sustainability of SES such as irrigation systems. As a significant user of water for irrigation purposes (Khan et al. 2010), the dairy industry in Australia provides a valuable lens on the issue of water governance because it has its own strategies and arrangements for influencing and supporting the activities and business strategies of dairy farmers. These strategies and arrangements may contain possibilities for workable, decentralized (Anderies et al. 2013) governance models.

In the context of the MDB and the modernization of the GMID, recent experience suggests that the incumbent governance arrangements are neither effective nor acceptable to the majority of stakeholders (Alston and Whittenbury 2011, Wallis et al. 2015). A recent independent review of progress on the Project found that it has not delivered the intended outcomes on time and within budget (GHD 2015) and the governance mechanisms highlighted in the original business case for the Project, such as "collective and proactive approach[es] to negotiation and agreement with the Project [G-MW Connections Project]," have been rare (GHD 2015:ii).

\section{METHODOLOGY}

We draw on two and a half years of empirical research from March 2012 to November 2014 with the Australian dairy industry and build on past research that has investigated the use of resilience thinking (Berkes 2007, Folke et al. 2010, Walker and Salt 2012a) as a guiding theory for planning and development in the dairy industry (Nettle et al. 2000, 2015; Love, Sharma, Boxelaar, et al. 2011, unpublishedmanuscript). An action research approach (Carr and Kemmis 1986) was used in the design and conduct of the research, which meant that it's focus and scope were iteratively determined in negotiation with the steering committee for the Project as key participants in the research (Table 2).

The steering committee had seven members who were selected to represent the different communities of practice (Wenger 1998) with roles and responsibilities for supporting irrigated dairy farmers to respond to the G-MW Connections Project in the Goulburn Murray Irrigation District. These communities of practice were identified from analysis of documents, interviews, and a focus group (see Appendix 1 for focus group questions) to be: irrigated dairy farming professionals; dairy industry professionals; and government professionals (Fig. 2). Communities of practice are characterized by shared sets of practices that include a "repertoire of tools, frameworks, methods and stories-as well as activities related to learning and innovation" (Snyder and Wenger 2004:4). This includes different practices for doing or enacting water governance (Law and Urry 2004).

Terms of Reference for the steering committee were collaboratively developed and agreed to at the commencement of the research and specified the role of the committee as: 
Table 2. Methods used, data gathered, and participants involved in the research.

\begin{tabular}{|c|c|c|c|}
\hline Dates & Type of data gathering & Research activity & Participants/Location \\
\hline March-December 2012 & $\begin{array}{l}\text { Document analysis } \\
\text { Participant observation }\end{array}$ & $\begin{array}{l}\text { Analysis of key documents aimed at resilience } \\
\text { assessment and participatory processes } \\
\text { Key interventions aimed at supporting dairy } \\
\text { farmers in the Murray Dairy region to manage } \\
\text { the challenges of water policy and } \\
\text { management change }\end{array}$ & Dairy industry stakeholders \\
\hline 8 March 2013 & Participant observation & $\begin{array}{l}\text { "Landowner Connections" (G-MW) } \\
\text { information sessions (3) }\end{array}$ & $\begin{array}{l}38 \text { irrigators at three meetings in } \\
\text { Numurkah and Cobram, Victoria }\end{array}$ \\
\hline 12 May 2013 & Participant observation & $\begin{array}{l}\text { "Water Basics for Women" (community group) } \\
\text { workshop }\end{array}$ & 9 community members, Cohuna \\
\hline 27 March 2013 & Participant observation & $\begin{array}{l}\text { "The Water Puzzle: Putting the Pieces } \\
\text { Together" (Murray Dairy forum) }\end{array}$ & 23 irrigated dairy farmers at Tallygaroopna \\
\hline 5 December 2012 & Participant observation & Murray Dairy business forum & \\
\hline $\begin{array}{l}17 \text { April } 2012 \\
30 \text { October } 2012 \\
11 \text { December } 2012 \\
9 \text { December } 2013 \\
14 \text { May } 2014\end{array}$ & & $\begin{array}{l}\text { Five meetings of the steering committee } \\
\text { (comprising eight members) of the project }\end{array}$ & $\begin{array}{l}\text { Steering committee comprising } \\
\text { representatives of the dairy farming, dairy } \\
\text { industry professional, and government } \\
\text { communities of practice }\end{array}$ \\
\hline 13 March 2013 & Focus group interview & $\begin{array}{l}\text { Facilitated discussion involving dairy farmers } \\
\text { and service providers in the Goulburn Murray } \\
\text { Irrigation District. (See Appendix } 1 \text { for focus } \\
\text { group questions.) }\end{array}$ & $\begin{array}{l}\text { Members of Murray Dairy Business } \\
\text { Network ( } 10 \text { people) }\end{array}$ \\
\hline 5 May 2014 & Workshop intervention & $\begin{array}{l}\text { Workshop on "Managing the Regional Change } \\
\text { Challenge: the G-MW Connections Project" }\end{array}$ & $\begin{array}{l}\text { Steering committee members } \\
\text { (dairy industry leaders) (eight participants: } \\
\text { two dairy farmers; three dairy industry } \\
\text { professionals involved in dairy industry } \\
\text { development); one key government } \\
\text { stakeholder (one person) }{ }^{\dagger} \text {; researchers } \\
\text { (two) and facilitator (one) }\end{array}$ \\
\hline
\end{tabular}

${ }^{\dagger}$ Another representative of the government professional community of practice was unable to attend at the last minute.

- To provide balanced comments on dairy industry and community issues and ideas.

- To provide a conduit to the dairy industry and regional communities that will assist in monitoring industry and community attitudes to ensure the research is reflective of dairy industry priorities.

- To identify possible future opportunities for dairy industry engagement and/or research in supporting regional resilience and irrigation futures.

We developed an analysis framework (Table 3 ) to structure closed thematic coding of the research data in the software package NVIVO 10. This framework included three rounds of coding. In the first round of coding, we applied the concept of communities of practice originally proposed by Wenger (1998) to identify responses and attributes of the different knowledge communities in irrigated dairying. In the second round, we applied the concept of adaptive governance and the coding categories were dimensions of adaptive governance identified from the literature (Walker et al. 2004). And in the third round of coding, we adapted Shapin and Schaffer's (1985) typology of knowledge technologies to a typology of knowledge practices to explore the symbols, materials, and social arrangements emergent in the resilience assessment intervention.
Data sources for the research were documents relating to water and irrigation management in the GMID, transcripts of interviews and a focus group, a report of the focus group, written records of steering committee meetings, and researchers' notes from participant observation. Table 2 summarizes the methods used, data gathered, and participants involved in the research.

\section{Codesigning a governance intervention}

Two research-practice activities were the main focus of our research: the development of a "workbook for assessing change challenges in dairy regions" (the new workbook; Rural Innovation Research Group 2013) and, the codesign of a governance intervention aimed at coordinating support to dairy farmers responding to irrigation modernization.

Together with members of the steering committee, we (as researchers and participants) resolved to design a practical intervention to explore options for providing support to dairy farmers responding to the G-MW Connections Project. To do this, we used resilience concepts and activities from the Resilience Alliance's Workbook for Assessing Resilience in Socio-ecological Systems (the RA workbook; Resilience Alliance 2010) to develop a workbook specific to the issue of assessing change challenges (such as irrigation modernization) in dairy regions. This new workbook entitled, Assessing Change Challenges in Dairy Regions, aims to enable deliberation (Lebel et al. 2006) and 
Fig. 2. Communities of practice in irrigated dairying in the Goulburn Murray Irrigation District, Australia.
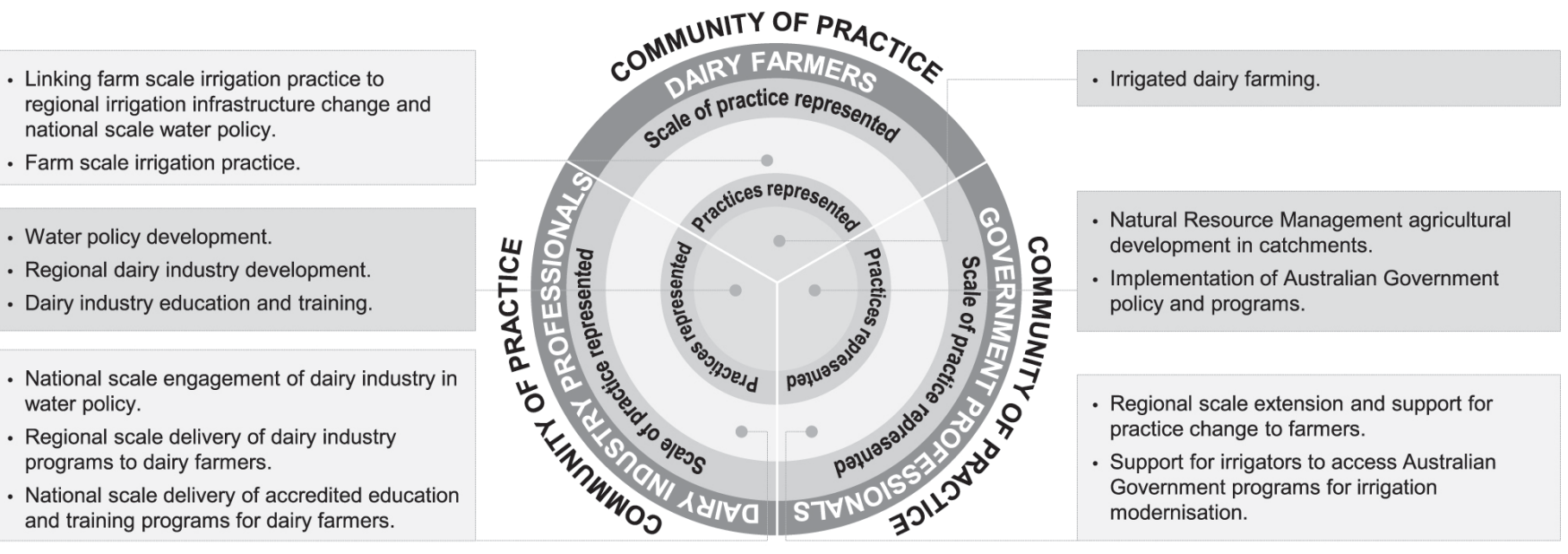

strategic planning and includes seven steps of resilience assessment (Fig. 3).

Using the new workbook, we deliberated with members of the Project steering committee to design a one-day workshop (the workbook intervention) held in Echuca, Victoria on 23 May, 2014. We selected and organized elements of the new workbook (Fig. 3) to address resilience dimensions relevant to dairy industry change management and the irrigation modernization challenge. Because of time constraints, we were not able to include all activities from the new workbook and therefore the opportunity to reflect on the utility of applying some resilience concepts was limited.

Fig. 3. Steps in workbook for assessing change challenges in dairy regions showing resilience concepts and activities used.

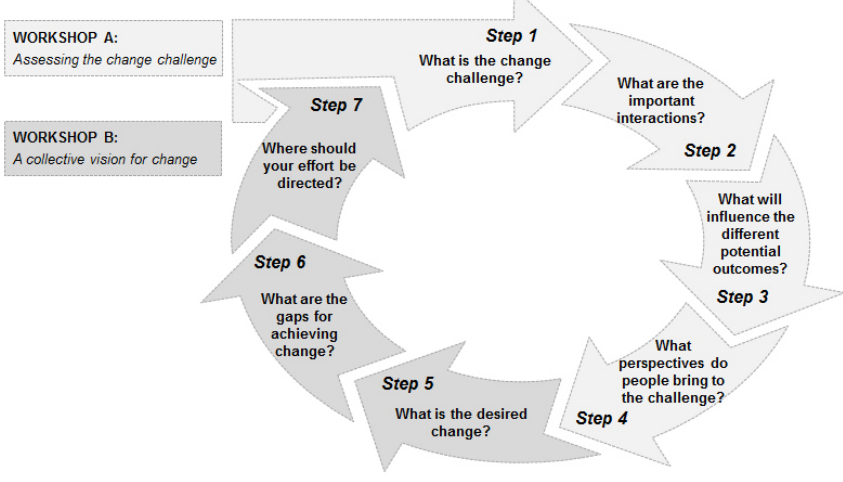

\section{Reflections on our role as researchers-participants}

As researchers-participants (Schon 1984), we strove throughout our inquiry to continually reflect on and to communicate our own interests and agendas, as well as to engage productively with those of other participants, and thus meet two key challenges of managing confirmation bias in our research: articulating our prior assumptions; and, engaging in group deliberations to share and validate different assumptions and viewpoints (Phillips and Burbules 2000). We did this through the documentation of ongoing interactions between ourselves and other participants, including sharing and validating detailed records of all project activities (e.g., meeting minutes, workshop reports). Risks associated with the Project included a potential lack of engagement of dairy industry stakeholders in a two and a half year project that relied on the participation over time of relevant individuals as well as ongoing institutional commitment and support. For example, because of the evolving dynamics of water management in northern Victoria, our original intention to engage groups of dairy farmers in a deliberative workshop process was not pursued. TRAhe Project steering committee members were therefore the key participants in the research. The trust and working relationships members built in the intervening period between the establishment of the steering committee (in 2012) and the workshop intervention (mid 2014) described contributed to the outcomes achieved.

\section{RESULTS}

In session 1 of the workbook intervention (drawn from step 1, "What is the change challenge?" of the new workbook), participants characterized and critically reviewed the change (governance) challenge of the G-MW Connections Project and identified the key issues (Walker et al. 2009) for dairy farmers, the dairy industry, and the region (Table 3 ). They also responded to the question: "How have stakeholders reacted to the G-MW Connections Project so far?" and completed a draft list of key stakeholders in the challenge. Resilience concepts applied were: components, boundaries, problems and values (Walker et al. 2009) related to the governance challenge; geographic and temporal scales (Folke et al. 2010) of governance activity; and, the key [human] actors (Folke et al. 2010) with different roles and influences on the governance challenge.

Some resilience concepts, in particular, enabled new understandings to emerge (Table 4). For example, by focusing on key systems dynamics, such as the various perspectives and interactions of stakeholders (Miller et al. 2010) and the threats and opportunities (Folke et al. 2010) for change, participants 
Table 3. Analysis framework for exploring adaptive governance practices in irrigated dairying.

\begin{tabular}{|c|c|c|c|}
\hline Broad disciplinary approach & Literature source & Coding round & Coding categories \\
\hline Sociology & Wenger 2000 & Round 1 & Communities of practice. \\
\hline Resilience theory on & Folke et al. 2005 & Round 2 & Dimensions of adaptive governance: \\
\hline dimensions of adaptive & Stoker 1998 & \multirow{8}{*}{ Round 3} & roles and practices (e.g., leadership); \\
\hline governance in social-ecological & Engle and Lemos 2010 & & learning opportunities and evidence; \\
\hline systems (SES) & Armitage 2005 & & self-organization; \\
\hline \multirow{5}{*}{$\begin{array}{l}\text { Science and technology studies } \\
\text { (STS) }\end{array}$} & \multirow{5}{*}{ Shapin and Schaffer 1985} & & $\begin{array}{l}\text { cross-scale interactions; } \\
\text { engagement and deliberation. }\end{array}$ \\
\hline & & & Typology of knowledge \\
\hline & & & practices \\
\hline & & & symbols and representational practices; \\
\hline & & & $\begin{array}{l}\text { material resources; } \\
\text { social arrangements. }\end{array}$ \\
\hline
\end{tabular}

reflected that irrigation modernization relies on links, or what resilience scholars would describe as cross-scale interactions (Walker et al. 2004) or connectivity (Janssen et al. 2006), between multiple levels in the governance system:

Table 4. Key issues identified by regional water managers related to the G-MW Connections Project.

\section{Key Issues}

Dealing with uncertainty related to the constancy of water policy change and lack of clear time frames for change processes (such as the the G-MW Connections Project).

Potential for creating inequities within irrigation communities/regions from irrigation modernization.

Controlling the change (G-MW Connections Project) through incentives for particular measures.

Maintaining profitability (of dairy businesses) while gaining water efficiencies through modernization incentives programs.

Unbundling of water from land as part of high level water policy initiatives.

Strategic connections projects (SCP) require support for group decision making.

Access to independent and trusted advisors.

[the workbook intervention is..] Also to develop links [for managing irrigation modernization], not just between individuals, but between organizations too. (participant, 7, 5/5/14)

Regional change [e.g., irrigation modernization] is the summation of individual change. And it therefore involves linkages between all levels [of activity/governance], like community, regional, state, and national [levels]. (participant, 1, 5/5/15)

In session 2 of the workbook intervention (drawn from step 4: "What perspectives do people bring to the challenge?"), participants identified the dynamics of stakeholder participation in the multilevel governance system (Pahl-Wostl 2009) of irrigation modernization. Therefore steering committee members described and deliberated on the following dimensions of governance in SES: the roles, commitments, and activities of different stakeholders in supporting dairy farmers to respond to the Project including their reactions and responses to date, and the connections and disconnections between human and institutional actors at different governance levels of the change challenge (Pahl-Wostl 2009). By focusing on the roles and relationships between people and institutions, participants created a joint representation of the level of engagement of different stakeholder organizations in governing the Project, in the form of a metaphor of the swimming pool. This metaphor represents what participants considered the current level of activity and commitment of different organizations to fulfilling their governance roles and associated responsibilities (Fig. 4). It enabled participants to manage the complexity of the governance challenge by operating as a boundary object (Star and Greismer 1989) through which they could negotiate and settle on a shared understanding of the different roles and level of engagement of organizations in supporting dairy farmers' response to the Project.

Fig. 4. Metaphor of the roles of different organizations in supporting dairy farmers in the Goulburn Murray Irrigation District to respond to the G-MW Connections Project.

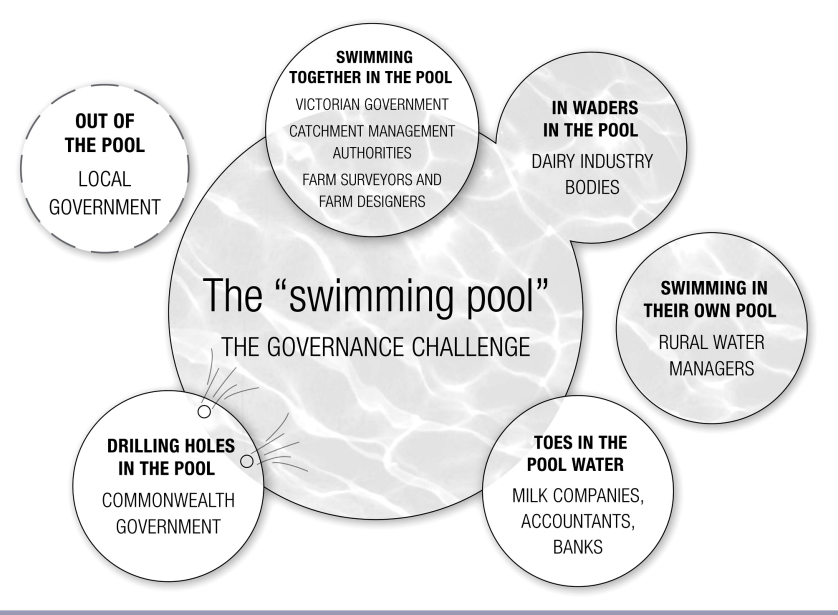


In session 3, participants built on the shared understandings and representations (e.g., the swimming pool metaphor) that emerged from the earlier sessions, to identify possibilities for enacting future responses to the Project. Applying the resilience concepts of scales (of activity and governance), drivers of change (in SES), and identifying opportunities and threats (Folke et al. 2010), participants deliberated on potential actions and then negotiated a list of 14 joint strategic actions (Table 4), which were then refined to 5 priority strategic actions (Table 5). These actions are not currently represented in the strategic planning agendas of the key organizations represented in the intervention. Therefore, this list consolidates new knowledge about what is required to support dairy farmers responses to the Project.

Table 5. Priority strategic actions identified to support dairy farmers responding to the G-MW Connections Project.

\begin{tabular}{|c|c|}
\hline Priority strategic action & Objective of the action \\
\hline $\begin{array}{l}\text { Way Forward/Alignment } \\
\text { Workshop. }\end{array}$ & $\begin{array}{l}\text { Key objectives would be: developing } \\
\text { a common vision and way forward; } \\
\text { sharing the load; assigning more } \\
\text { roles; to coordinate clear messages } \\
\text { to farmers/irrigators; to get people } \\
\text { back on page one together; } \\
\text { identifying some of the slow points } \\
\text { in the current change process and } \\
\text { what we can do about these. }\end{array}$ \\
\hline $\begin{array}{l}\text { Communicate the benefits of } \\
\text { modernization to farmers. }\end{array}$ & $\begin{array}{l}\text { To communicate the benefits that } \\
\text { farmers/irrigators may gain from } \\
\text { irrigation modernization in the } \\
\text { Goulburn Murray Irrigation } \\
\text { District. }\end{array}$ \\
\hline $\begin{array}{l}\text { Create and service the demand } \\
\text { for the "on-farm workbook" } \\
\text { (developed in the Innovative }\end{array}$ & $\begin{array}{l}\text { Use and develop capacity to create } \\
\text { demand for the on-farm workbook } \\
\text { and service that demand. }\end{array}$ \\
\hline Farming Program's Irrigation & Using the way forward/alignment \\
\hline $\begin{array}{l}\text { Modernization Project; NCCMA } \\
\text { 2013). }\end{array}$ & $\begin{array}{l}\text { workshop to communicate the } \\
\text { benefits of the on-farm workbook to } \\
\text { farmers, consultants, and advisers. }\end{array}$ \\
\hline $\begin{array}{l}\text { Obtaining resources to roll-out } \\
\text { the on-farm workbook Tool. }\end{array}$ & $\begin{array}{l}\text { Expand the influence and impact of } \\
\text { the on-farm workbook process. } \\
\text { Use existing capacity to service } \\
\text { demand. }\end{array}$ \\
\hline $\begin{array}{l}\text { Providing direct support to } \\
\text { landowner committees } \\
\text { (established for G-MW } \\
\text { Connections Project). }\end{array}$ & $\begin{array}{l}\text { Operational objective to provide } \\
\text { appropriate support to this } \\
\text { mechanism as part of the change } \\
\text { process. }\end{array}$ \\
\hline
\end{tabular}

Session 4 was drawn from the new workbook: step 6: "Where should your effort be directed?" Resilience concepts of learning and planning for future action (Marshall and Marshall 2007), and identifying stakeholder roles and responsibilities underpinned deliberation on the implementation of the strategic actions identified in session 3. Agreement was reached on the top five priority strategic actions (Table 4), with priority strategic action 1 being to hold an "alignment/way forward" workshop in September 2014. Despite this agreement, the alignment/way forward workshop did not occur. The third priority strategic action from the intervention was to "create and service the demand for the on-farm workbook" developed by the North Central Catchment Management Authority's Innovative Farming Irrigation Modernization Project (NCCMA 2013). This was pursued at the initiative of several of the key participants and was the subject of a major funding proposal in early 2015 by Dairy Australia.

The final session of the workbook intervention was a formal evaluation (Lebel et al. 2006) in which all participants rated the workshop overall as either extremely valuable or valuable for addressing a regional change challenge.

\section{DISCUSSION}

The results show that through the workshop intervention, the diverse interests and activities of water managers and users were aligned in ways that enabled new governance practices for responding to irrigation modernization to emerge.

\section{Resilience concepts enabled new understandings of the governance challenge}

In the workbook intervention described here, resilience thinking (Folke 2006) was a conceptual frame that enabled participants to better coordinate and align their water governance practices for responding to irrigation modernization. This coordination and alignment emerged as new insights and learning (Folke 2006) among water managers into what is required to address the governance challenge of the Project. For example, the list of strategic actions emerged as a new way of managing the uncertainty of the governance challenge. This list is a representation (or symbol) of the agreement among participants on what future collective action for governing irrigation modernization is desirable and possible. For example:

\section{I found it interesting that we all agreed on what the process [for supporting dairy farmers to respond to the Project] should be going forward. (participant 3, 5/5/14)}

It is important to note, however, that the workbook intervention did not address the resilience concept of governance directly. Although the new workbook has a section dedicated to governance (as does the RA workbook), there was not time to cover it in this intervention. Despite this, participants identified the need for a "way forward/alignment workshop" (Table 5). In naming this priority action as both a way forward and a process of alignment, participants recognized the need to further coordinate their governing practices in a future governance intervention. The alignment of governing practices has been identified by resilience and ANT scholars as a process of selforganization (Folke 2006) and translation (Callon 1986), respectively. The capacity to self-organize is a key attribute of adaptive governance (Lebel et al. 2006) and through the use of resilience concepts in the workbook intervention, participants built their capacity for future governance work as one person testified:

The outcome of this [workbook intervention] is... how we can do change together differently. (participant 6, 5/5/14)

Doing change differently in the case of the Project required symbolic practices or representations, such as the use of resilience concepts, to support new thinking for improved governance. When mobilized within groups, concepts or representational knowledge (Wagenaar and Wilkinson 2013) enable both shared meanings and new possibilities for action to emerge. Consistent with a critical appraisal of the Resilience Alliance's RA workbook by Davoudi et al. (2012), the new workbook, with its focus on 
resilience concepts, supported practitioners to think through the linkages between different governance entities and activities in quite different ways than the standard planning tools usually allow. In practice, however, governing irrigation modernization also requires material resources, such as the new workbook for resilience assessment, as well as particular social arrangements between different people and their organizations involved in irrigation modernization in the GMID.

\section{Resilience assessment workbooks help mobilize collective action} In contrast to normative understandings of resilience assessment workbooks as instrumental tools (Sellberg et al. 2015) to represent attributes of complex social-ecological systems, we suggest that, such workbooks are thoroughly performative of resilience theory and thinking when used by people in a group who engage with the resilience concepts they embody. By performative, we suggest that these resilience workbooks can be understood as having certain agency. This agency is demonstrated in the way that the new workbook in this research enabled different configurations of governing practices to emerge; for example in the form of new insights into the relevance of such workbooks for managing the diversity, complexity, and uncertainty of change processes in complex SES. As participants in the workshop intervention noted:

Regardless of what the change is, they'll still be same sound tools to help go through that [change] process. (participant 5, 27/5/15)

...[it's] easy to see generalizations [in the workbook process] that can be applied to other change challenges. (participant 10, 27/5/15)

Participants in the workbook intervention recognized that the mobilization of the new workbook in addressing the governance challenge of the Project was, however, the result of months of negotiations about how, when, and where it would be used and who should be involved. Hence, the role of the new workbook was not to provide a deterministic blueprint (Rijke et al. 2012) or template for action but rather to be used contingently depending on the issue and people involved:

It's really important that when we are dealing with a complex issue [such as G-MW Connections Project] that we don't just have a straight line... or simple template to address it. (participant 7, 16/5/15)

New social arrangements emerged from the use of resilience concepts and the new resilience assessment workbook

Possibilities for enacting resilience also emerged in the workbook intervention in the form of new social practices, including new agreements (e.g., progressing support to dairy farmers in the form of strategic actions), new relationships (e.g., establishment of an informal social network; Rijke et al. 2012), and potential new roles (e.g., new impetus for leadership). For example, by engaging with other water managers in the intervention, new alliances and linkages were enabled as participants noted:

...[In the workbook intervention]...I engaged with people and organizations that I don't normally engage with at such a deep level. (participant 5, 5/5/14)

[the workbook intervention identified]... a clear path forward for the dairy industry body. [And] Better understanding of and connection between stakeholders and their issues and how to address these together.. (participant 2, 5/5/14)

In addition to this, although participants all had an established prior role in supporting irrigated dairy farmers through their various institutional affiliations, identifying together what was needed to respond to the Project gave individuals the impetus to recognize and assume leadership as critical to building capacity to govern adaptively (Olsson et al. 2006). For example, they reflected that different types of leadership (Walker et al. 2006, Folke et al. 2010) at different levels would be required to govern irrigation modernization:

\section{...local leadership is pretty much essential to have a successful change process in a local or a regional context. (participant 3, 5/5/14) \\ Leadership at the regional scale is critical; it's been hard to get that going in this case [of responding to the G- MW Connections Project]. (participant 8, 5/5/14)}

Despite the best intentions of water managers involved in the workbook intervention, the priority strategic action 1, i.e., the way forward/alignment workshop did not go ahead. A limitation of the intervention recognized by participants was that not all key water management practice communities were adequately represented; there was only one representative from government and none from the relevant irrigation authority. And one participant questioned:

Whose job is it to make it all happen? (participant, 1, 5/5/14)

Another omission from the workbook intervention was the opportunity to enact the resilience of regional ecosystems through explicitly considering, for example, issues of sustainable water management, soil health, and landscape dynamics. This reflects the immediate concerns of participants, which related to how to better coordinate and influence the governance challenge of the Project for improved support to dairy farmers. We suggest that the workbook intervention enabled, what Chapple and Montero (2016) describe as, fragile governance, based on an enhanced capacity to learn and act together, which required further support and action in the form of leadership, financial resourcing, focus on environmental (along with social) impacts and dynamics, and ongoing institutional commitment to improved governance. A remaining research challenge is therefore to understand how the quality of the collective action for adaptive governance, including its sustainability, can be assured?

A science and technology studies (STS) framing helps understand what is required in practice to enable adaptive governance

In the STS framing we use from ANT, it is the combinations of different practices that produce (Callon 1986, Latour 2005) or perform (Mol 2002) possibilities for change, such as new ways of governing or governing practices. Through our empirical study of the workbook intervention described, we identify new ways of governing as emergent in the collective action of water managers as they make concerted efforts to coordinate and align their diverse knowledge practices through mobilizing new representations (e.g., swimming pool metaphor) and new material resources (e.g., the new workbook). By attending to the agency, not just of humans and their social practices of governing, but of 
symbolic practices (e.g., resilience concepts) and material practices (e.g., resilience assessment workbooks), we posit that the workbook intervention enabled adaptive governance through more than just assessment of resilience; it contained possibilities for enacting resilience.

The challenges and merits of enacting or practicing (Walker and Salt 2012b) resilience theory or resilience thinking have been increasingly acknowledged by resilience scholars (Marshall and Marshall 2007, Davoudi et al. 2012, Walker and Salt 2012b, Davidson et al. 2013). We suggest that resilience approaches can contribute beyond assessment of the status of SES, toward adaptive governance that is more aligned to the interests, needs, and aspirations of different people and groups as they negotiate shared resilience pathways. In practice, what is required to achieve such new ways of governing is the strategic mobilization of symbols and representations, material resources, and social arrangements through collective action. This mobilization is likely to emerge in times of urgency, such as when incumbent resource management and distribution systems are being altered or threatened.

The broader context for change is also a critical factor in enabling or constraining governance and although this research has not addressed this directly, we acknowledge that local governance responses will depend on the broader political, social, and environmental factors affecting irrigation communities and their places. In the case of irrigation modernization, this will require ongoing investment and commitment by regional change leaders and their organizations in collective action that enables the full range of people and groups with values and interests in water to align their diverse governing practices for improved outcomes.

To guide regional change managers and others in their governance endeavors, we propose a conceptual framework of collective action for adaptive governance (Fig. 5). This framework recognizes the symmetrical importance of: symbolic (or representational) practices (e.g., resilience concepts); material practices for translating resilience concepts, such as resilience assessment workbooks (O'Connell et al. 2015); and, the social practices of resource managers and institutions (e.g., deliberation, agreement making). The framework identifies examples of such practices from the workbook intervention described, including: new symbolic practices of metaphor and listing strategic actions; the new workbook document itself; and, the new alliances and roles of people and organizations involved in managing change. This framework highlights the importance of resilience concepts and resilience assessment tools as key strategic practices for enacting adaptive governance.

We acknowledge that a limitation to this research was that the workbook intervention didn't consider some aspects of the wider context of SES resilience; in particular it didn't comprehensively consider the ecological dynamics related to dairying and irrigation modernization.

\section{CONCLUSION}

Agricultural industries and rural communities worldwide are faced with improving outcomes for society and the environment from major change initiatives, such as irrigation modernization. The resilience scholarship has contributed to global understanding and appreciation of the complexity, diversity, and uncertainty inherent in such change processes through assessing what is needed to respond and ensure improved outcomes for communities and their places. We demonstrate possibilities for moving beyond assessment to the operationalization or enactment of resilience approaches, through connecting resilience theory with constructivist theoretical perspectives on collective action from STS.

Fig. 5. A conceptual framework for collective action for adaptive governance.

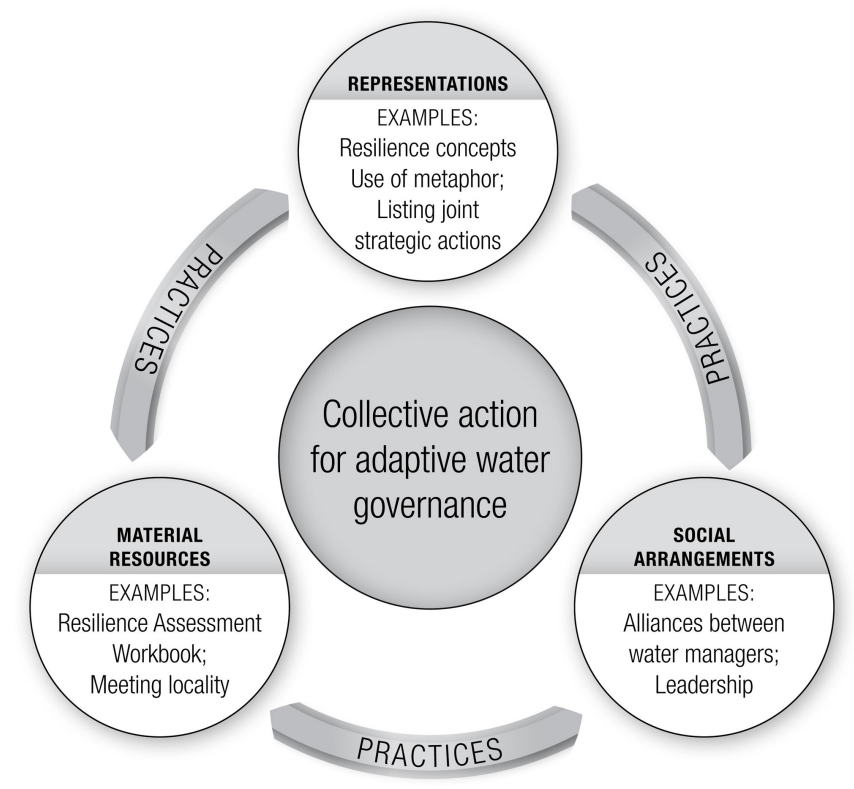

Through collaborative research with members of irrigated dairying communities of practice, we have shown that an adaptive governance intervention, designed using resilience concepts and a resilience assessment workbook, enabled water users, water managers, and dairy industry professionals to better recognize, account for, and align their diverse governance practices. This was achieved through the mobilization of resilience concepts and tools (e.g. resilience assessment workbooks), through deliberation and interaction across the different communities of practice in irrigated dairying, and by engendering commitment from people and their institutions to collectively respond to and lead within the irrigation modernization change process. This is important for both practitioners and scholars because it expands the conception of resilience thinking and assessment methods (such as the RA workbook) as the application of either cognitive or operational tools (Miller et al. 2010), to one that recognizes the agency of such concepts and tools in enacting resilience for adaptive governance. In the case of governing irrigation modernization, aligning governing practices enabled regional change leaders to identify opportunities and priorities for improved governance that were not previously recognized or mutually supported.

By providing a perspective from an irrigated agricultural industry, this research also reveals different features of adaptive governance than would be revealed by looking solely from the perspective of government and/or regional natural resource management 
bodies. Notably, it shows the heterogeneity of practices for water governing within the dairy industry itself and the value of these for collective action toward improved governance outcomes for people and their places in the Murray Darling Basin. In other studies, industry is often framed as just a stakeholder; however, this research shifts attention to the active role and contributions of an agricultural industry. This industry lens is important because enacting resilience for improved governance of sustainability challenges requires the full range of societal actors and their governance practices to be engaged in regional-scale change processes.

The research project detailed was a catalyst to mobilize regional change leaders toward a form of adaptive governance. However, to sustain this fragile governance (Chapple and Montero 2016), leaders in both government and industry need to invest in further governance efforts, such as creating roles for leading interventions (such as the one described), as well as incentivizing participation through formal recognition of coordination and facilitation of these activities as core capacities for government and industry change leaders. Although this governance work is challenging, evidence that it is required is clearly provided in the case of irrigation modernization in the GMID, in which justice criteria have not been met (Primary Agency 2016) and in which, despite huge investment of monetary and technical resources over a three year period, incumbent governance efforts have floundered and now require a reset (Goulburn-Murray Water 2016).

Responses to this article can be read online at: http://www.ecologyandsociety.org/issues/responses. $\mathrm{php} / 9256$

\section{Acknowledgments:}

We acknowledge funding from Dairy Australia for this project and thank Murray Dairy, the dairy farmers, service providers, and government personnel who participated in this project, particularly the members of the Project Steering Committee for their interest, support, and for sharing their expert knowledge and experiences. We also thank Callum Eastwood, Catherine Botta, and Tamara Sysak for their advice and support.
\end{abstract}

\section{LITERATURE CITED}

Addelson, K. P. 1994. Moral passages: toward a collectivist moral theory. Routledge, New York, New York, USA.

Adger, W. N. 2010. Social capital, collective action and adaptation to climate change. Pages 327-345 in Der Klimawandel: Sozialwissenschaftliche Perspektiven. Springer, Berlin, Germany.

Alston, M. 2012. Synthesis paper on socioeconomic factors relating to agriculture and community development. Crop and Pasture Science 63:232-239. http://dx.doi.org/10.1071/CP11173

Alston, M., and K. Whittenbury. 2011. Climate change and water policy in Australia's irrigation areas: a lost opportunity for a partnership model of governance. Environmental Politics 20:899-917. http://dx.doi.org/10.1080/09644016.2011.617175
Anderies, J. M., C. Folke, B. Walker, and E. Ostrom. 2013. Aligning key concepts for global change policy: robustness, resilience, and sustainability. Ecology and Society 18(2):8. http:// dx.doi.org/10.5751/es-05178-180208

Armitage, D. 2005. Adaptive capacity and community-based natural resource management. Environmental Management 35 (6):703-715. http://dx.doi.org/10.1007/s00267-004-0076-Z

Ayre, M., and R. Nettle. 2015. Doing integration in catchment management research: insights into a dynamic learning process. Environmental Science and Policy 47:18-31. http://dx.doi. org/10.1016/j.envsci.2014.10.011

Bahadur, A. V., M. Ibrahim, and T. Tanner. 2010. The resilience renaissance? Unpacking of resilience for tackling climate change and disasters. Strengthening climate resilience discussion paper 1 . Institute of Development Studies, Brighton, UK.

Barnes, J., and S. Alatout. 2012. Water worlds: introduction to the special issue of Social Studies of Science. Social Studies of Science 42:483-488. http://dx.doi.org/10.1177/0306312712448524

Bell, A. R., N. L. Engle, and M. C. Lemos. 2011. How does diversity matter? The case of Brazilian river basin councils. Ecology and Society 16(1):42. http://dx.doi.org/10.5751/ es-04019-160142

Berkes, F. 2007. Understanding uncertainty and reducing vulnerability: lessons from resilience thinking. Natural Hazards 41:283-295. http://dx.doi.org/10.1007/s11069-006-9036-7

Blackmore, C., R. Ison, and J. Jiggins. 2007. Social learning: an alternative policy instrument for managing in the context of Europe's water. Environmental Science and Policy 10:493-498. http://dx.doi.org/10.1016/j.envsci.2007.04.003

Blomquist, W. 1992. Dividing the waters: governing groundwater in Southern California. Institute for Contemporary Studies, Tirana, Albania.

Brown, V. A., and J. A. Lambert. 2012. Collective learning for transformational change: a guide to collaborative action. Routledge, London, UK.

Callon, M. 1986. Some elements of a sociology of translation: domestication of the scallops and the fisherman of St. Brieuc Bay. Pages 196-223 in J. Law, editor. Power, action and belief: a new sociology of knowledge. Sociological Review Monograph 32. Routledge and Kegan Paul, London, UK.

Callon, M., and J. Law. 1989. On the construction of sociotechnical networks: content and context revisited. Knowledge and Society 8(1):57-83.

Carr, W., and S. Kemmis. 1986. Becoming critical: education, knowledge and action research. Routledge, London, UK.

Carroll, P. 2012. Water and technoscientific state formation in California. Social Studies of Science 42:489-516. http://dx.doi. org/10.1177/0306312712437977

Chapple, K., and S. Montero. 2016. From learning to fragile governance: regional economic development in rural Peru. Journal of Rural Studies 44:143-152. http://dx.doi.org/10.1016/j. jrurstud.2016.01.009 
Collett, B., and N. Henry. 2014. Water justice: exploring the social dimensions of new irrigation technologies in northern Victoria, Australia. Water Policy 16(S2):155-173. http://dx.doi.org/10.2166/ wp.2014.102

Cook, B. R., M. Kesby, I. Fazey, and C. Spray. 2013. The persistence of 'normal' catchment management despite the participatory turn: exploring the power effects of competing frames of reference. Social Studies of Science 43:754-779. http:// dx.doi.org/10.1177/0306312713478670

Daniell, K. A. 2013. Practical responses to water and climate policy implementation challenges. Australian Journal of Water Resources 17(2):111-125.

Daniell, K. A., I. White, N. Ferrand, I. S. Ribarova, P. Coad, J.E. Rougier, M. Hare, N. A. Jones, A. Popova, D. Rollin, P. Perez, and S. Burn. 2010. Co-engineering participatory water management processes: theory and insights from Australian and Bulgarian interventions. Ecology and Society 15(4):11. http://dx. doi.org/10.5751/es-03567-150411

Davidson, J. L., I. E. van Putten, P. Leith, M. J. Nursey-Bray, E. M. Madin, and N. J. Holbrook. 2013. Toward operationalizing resilience concepts in Australian marine sectors coping with climate change. Ecology and Society 18(3):4. http://dx.doi. org/10.5751/es-05607-180304

Davoudi, S., K. Shaw, L. J. Haider, A. E. Quinlan, G. D. Peterson, C. Wilkinson, H. Fünfgeld, D. McEvoy, L. Porter, and S. Davoudi. 2012. Resilience: a bridging concept or a dead end? "Reframing" resilience: challenges for planning theory and practice interacting traps: resilience assessment of a pasture management system in Northern Afghanistan urban resilience: what does it mean in planning practice? Resilience as a useful concept for climate change adaptation? The politics of resilience for planning: a cautionary note: edited by Simin Davoudi and Libby Porter. Planning Theory and Practice 13(2):299-333. http://dx.doi. org/10.1080/14649357.2012.677124

Devaux, A., D. Horton, C. Velasco, G. Thiele, G. López, T. Bernet, I. Reinoso, and M. Ordinola. 2009. Collective action for market chain innovation in the Andes. Food Policy 34:31-38. http://dx. doi.org/10.1016/i.foodpol.2008.10.007

Dwiartania, A., and C. Rosin. 2014. Exploring agency beyond humans: the compatability of actor-network theory (ANT) and resilience thinking. Ecology and Society 19(3):28. http://dx.doi. org/10.5751/ES-06805-190328

Engle, N. L., and M. C. Lemos. 2010. Unpacking governance: building adaptive capacity to climate change of river basins in Brazil. Global Environmental Change 20(1):4-13. http://doi. org/10.1016/j.gloenvcha.2009.07.001

Enserink, B., M. Patel, N. Kranz, and J. Maestu. 2007. Cultural factors as co-determinants of participation in river basin management. Ecology and Society 12(2):24. http://dx.doi. org/10.5751/es-02096-120224

Fish, R. D., A. A. R. Ioris, and N. M. Watson. 2010. Integrating water and agricultural management: collaborative governance for a complex policy problem. Science of the Total Environment 408:5623-5630. http://dx.doi.org/10.1016/j.scitotenv.2009.10.010
Folke, C. 2003. Freshwater for resilience: a shift in thinking. Philosophical Transactions of the Royal Society B: Biological Sciences 358(1440):2027-2036. http://dx.doi.org/10.1098/rstb.2003.1385

Folke, C. 2006. Resilience: the emergence of a perspective for social-ecological systems analyses. Global Environmental Change 16:253-267. http://dx.doi.org/10.1016/j.gloenvcha.2006.04.002

Folke, C., S. R. Carpenter, B. Walker, M. Scheffer, T. Chapin, and J. Rockström. 2010. Resilience thinking: integrating resilience, adaptability and transformability. Ecology and Society 15(4):20. http://dx.doi.org/10.5751/es-03610-150420

Folke, C., T. Hahn, P. Olsson, and J. Norberg. 2005. Adaptive governance of social-ecological systems. Annual Review of Environment and Resources 30:441-473. http://dx.doi.org/10.1146/ annurev.energy.30.050504.144511

GHD. 2015. Goulburn-Murray water connections project stage 2 mid-term review: final report. Department of Agriculture and Water Resources, Canberra, Australia. [online] URL: http://www. g-mwater.com.au/downloads/gmw/MTR/5_November_2015 GHD MTR Review Report.pdf

Gibbons, M., C. Limoges, H. Nowotny, S. Schwartzman, P. Scott, and M. Trow. 1994. Thenew production of knowledge: the dynamics of science and research in contemporary societies. Sage, Thousand Oaks, California, USA.

Goulburn-Murray Water. 2016. Connections project reset delivery plan summary. Goulburn-Murray Water, Tatura, Victoria, Australia. [online] URL: http://www.connectionsproject.com.au/ wp-content/uploads/2016/09/Report-SummaryRDP-Final-1.pdf

Haider, J. L., A. Quinlan, and G. D. Peterson. 2012. Interacting traps: resilience assessment of a pasture management system in northern Afghanistan. Planning Theory and Practice 13:299-333.

Hargrave, T. J., and A. H. Van De Ven. 2006. A collective action model of institutional innovation. Academy of Management Review 31:864-888. http://dx.doi.org/10.5465/AMR.2006.22527458

Head, B. W. 2010. Water policy: evidence, learning and the governance of uncertainty. Policy and Society 29:171-180. http:// dx.doi.org/10.1016/j.polsoc.2010.03.007

Hellin, J. 2012. Agricultural extension, collective action and innovation systems: Lessons on network brokering from Peru and Mexico. Journal of Agricultural Education and Extension 18:141-159. http://dx.doi.org/10.1080/1389224X.2012.655967

Ison, R., C. Blackmore, and B. L. Iaquinto. 2013. Towards systemic and adaptive governance: exploring the revealing and concealing aspects of contemporary social-learning metaphors. Ecological Economics 87:34-42. http://dx.doi.org/10.1016/j. ecolecon.2012.12.016

Ison, R., K. Collins, J. Colvin, J. Jiggins, P. P. Roggero, G. Seddaiu, P. Steyaert, M. Toderi, and C. Zanolla. 2011. Sustainable catchment managing in a climate changing world: new integrative modalities for connecting policy makers, scientists and other stakeholders. Water Resources Management 25:3977-3992. http:// dx.doi.org/10.1007/s11269-011-9880-4

Ison, R. L., K. B. Collins, and P. J. Wallis. 2015. Institutionalising social learning: towards systemic and adaptive governance. 
Environmental Science and Policy 53:105-117. http://dx.doi. org/10.1016/j.envsci.2014.11.002

Janssen, M. A., Ö. Bodin, J. M. Anderies, T. Elmqvist, H. Ernstson, R. R. J. McAllister, P. Olsson, and P. Ryan. 2006. Toward a network perspective of the study of resilience in socialecological systems. Ecology and Society 11(1):15. http://dx.doi. org/10.5751/es-01462-110115

Khan, S., A. Abbas, T. Rana, and J. Carroll. 2010. Dairy water use in Australian dairy farms: past trends and future prospects. CSIRO Water for a healthy country national research flagship, CSIRO, Canberra, Australia.

Latour, B. 1987. Science in action: how to follow scientists and engineers through society. Harvard University Press, Cambridge, Massachusetts, USA.

Latour, B. 1999. Pandora's hope: essays on the reality of science studies. Harvard University Press, Cambridge, Massachusetts, USA.

Latour, B. 2005. Reassembling the social: an introduction to actornetwork theory. Oxford University Press, Oxford, UK. [online] URL: http://dss-edit.com/plu/Latour Reassembling.pdf

Law, J. 1992. Notes on the theory of the actor-network: ordering, strategy, and heterogeneity. Systemic Practice and Action Research 5(4):379-393. http://dx.doi.org/10.1007/BF01059830

Law, J. 1999. After ANT: complexity, naming and topology. Sociological Review 47(S1):1-14. http://dx.doi.org/10.1111/ j.1467-954X.1999.tb03479.x

Law, J. 2004. After method: mess in social science research. Routledge, Abingdon, UK.

Law, J. 2012. Technology and heterogeneous engineering: the case of Portuguese expansion. In W. E. Bijker, T. P. Hughes, and T. Pinch, editors. The social construction of technological systems: new directions in the sociology and history of technology. MIT Press, Cambridge, Massachusetts, USA.

Law, J., and A. Mol. 1998. On metrics and fluids. Pages 18-35 in R. C. H. Chia, editor. Organized worlds: explorations in technology and organization with Robert Cooper. Routledge, New York, New York, USA.

Law, J., and J. Urry. 2004. Enacting the social. Economy and Society 33(3):390-410. http://dx.doi.org/10.1080/0308514042000225716

Lebel, L., J. M. Anderies, B. Campbell, C. Folke, S. HatfieldDodds, T. P. Hughes, and J. Wilson. 2006. Governance and the capacity to manage resilience in regional social-ecological systems. Ecology and Society 11(1):19. http://dx.doi.org/10.5751/ es-01606-110119

Marshall, N. A., and P. A. Marshall. 2007. Conceptualizing and operationalizing social resilience within commercial fisheries in northern Australia. Ecology and Society 12(1):1. http://dx.doi. org/10.5751/es-01940-120101

Miller, F., H. Osbahr, E. Boyd, F. Thomalla, S. Bharwani, G. Ziervogel, B. Walker, J. Birkmann, S. Van der Leeuw, J. Rockström, J. Hinkel, T. Downing, C. Folke, and D. Nelson. 2010. Resilience and vulnerability: complimentary or conflicting concepts? Ecology and Society 15(3):11. [online] URL: http:// www.ecologyandsociety.org/vol15/iss3/art11/

Mitchell, M. 2013. From organisational learning to social learning: a tale of two organisations in the Murray-Darling Basin. Rural Society 22:230-241. http://dx.doi.org/10.5172/rsj.2013.22.3.230

Mitchell, M., R. Griffith, P. Ryan, G. Walkerden, B. Walker, V. A. Brown, and S. Robinson. 2014. Applying resilience thinking to natural resource management through a "planning-by-doing" framework. Society and Natural Resources 27:299-314. http://dx. doi.org/10.1080/08941920.2013.861556

Mol, A. 2002. The body multiple: ontology in medical practice. Duke University Press, London, UK. http://dx.doi. org/10.1215/9780822384151

Mostert, E., M. Craps, and C. Pahl-Wostl. 2008. Social learning: the key to integrated water resources management? Water International 33:293-304.

Nelson, R., M. Howden, and M. S. Smith. 2008. Using adaptive governance to rethink the way science supports Australian drought policy. Environmental Science and Policy 11:588-601. http://dx.doi.org/10.1016/j.envsci.2008.06.005

Nettle, R., M. Ayre, R. Beilin, S. Waller, L. Turner, A. Hall, L. Irvine, and G. Taylor. 2015. Empowering farmers for increased resilience in uncertain times. Animal Production Science 55:843-855. http://dx.doi.org/10.1071/AN14882

Nettle, R., and M. Paine. 2009. Water security and farming systems: implications for advisory practice and policy-making. Journal of Agricultural Education and Extension 15:147-160. http://dx.doi.org/10.1080/13892240902909072

Nettle, R. A., P. G. H. Van Beek, M. A. Paine, and S. Jefford. 2000. Towards self-managed, interest-specific, farmer learning groups: a case study, action research project in the dairy industry. Fifth world congress on action learning, action research and process management. University of Ballarat, Ballarat, Victoria, Australia.

North Central Catchment Management Authority (NCCMA). 2013. Innovative farming irrigation modernisation project. North Central Catchment Management Authority, Bendigo, Australia. [online] URL: http://www.nccma.vic.gov.au/sites/default/files/ publications/innovativefarmingprogramjune2013.pdf

O'Connell, D., B. Walker, N. Abel, and N. Grigg. 2015. The resilience assessment, adaptation and transformation assessment framework: from theory to application. Discussion paper for the Scientific and Technical Advisory Panel of the Global Environment Facility. CSIRO, Canberra, Australia. [online] URL: http://www.stapgef.org/sites/default/files/documents/CSIROSTAP-Resilience-Adaptation-Transformation-Assessment-FrameworkReport.pdf

Olsson, Jr., M. 2009. The logic of collective action: public goods and the theory of groups. Harvard University Press, Cambridge, Massachusetts, USA.

Olsson, P., C. Folke, and F. Berkes. 2004. Adaptive comanagement for building resilience in social-ecological systems. Enviromental Management 34:75-90. http://dx.doi.org/10.1007/s00267-003-0101-7 
Olsson, P., L. H. Gunderson, S. R. Carpenter, P. Ryan, L. Lebel, C. Folke, and C. S. Holling. 2006. Shooting the rapids: navigating transitions to adaptive governance of social-ecological systems. Ecology and Society 11(1):18. http://dx.doi.org/10.5751/ es-01595-110118

Orr, P., J. Colvin, and D. King. 2007. Involving stakeholders in integrated river basin planning in England and Wales. Water Resources Management 21:331-349. http://dx.doi.org/10.1007/ $\underline{\text { s11269-006-9056-9 }}$

Ostrom, E. 1990. Governing the commons: the evolution of institutions for collective action. Cambridge University Press, Cambridge, UK. [online] URL: http://wtf.tw/ref/ostrom 1990. pdf

Ostrom, E. 2005. Policies that crowd out reciprocity and collective action. Pages 253-275 in H. Gintis, S. Bowles, R. Boyd, and E. Fehr, editors. Moral sentiments and material interests: the foundations of cooperation in economic life. MIT Press, Cambridge, Massachusetts, USA.

Ostrom, E. 2007. A diagnostic approach for going beyond panaceas. Proceedings of the National Academy of Sciences 104:15181-15187. http://dx.doi.org/10.1073/pnas.0702288104

Ostrom, E., and T. K. Anh. 2008. The meaning of social capital and its link to collective action. Pages 17-35 in G. T. Svendsen and G. L. Svendsen, editors. Handbook on social capital. Edward Elgar, Cheltenham, UK.

Ostrom, E., and R. Gardner. 1993. Coping with asymmetries in the commons: self-governing irrigation systems can work. Journal of Economic Perspectives7(4):93-112. http://dx.doi.org/10.1257/ jep.7.4.93

Pahl-Wostl, C. 2007a. The implications of complexity for integrated resources management. Environmental Modelling and Software 22:561-569. https://doi.org/10.1016/j.envsoft.2005.12.024

Pahl-Wostl, C. 2007b. Transitions towards adaptive management of water facing climate and global change. Water Resources Management 21:49-62. http://dx.doi.org/10.1007/978-1-4020-5591-1_4

Pahl-Wostl, C. 2009. A conceptual framework for analysing adaptive capacity and multi-level learning processes in resource governance regimes. Global Environmental Change 19(3):354-365. http://dx.doi.org/10.1016/j.gloenvcha.2009.06.001

Pahl-Wostl, C., and N. Kranz. 2010. Water governance in times of change. Environmental Science and Policy 13:567-570. http:// dx.doi.org/10.1016/j.envsci.2010.09.004

Pahl-Wostl C., L. Lebel, C. Knieper, and E. Nikitina. 2012. From applying panaceas to mastering complexity: toward adaptive water governance in river basins. Environmental Science and Policy 23:24-34. http://dx.doi.org/10.1016/j.envsci.2012.07.014

Pahl-Wostl, C., E. Mostert, and D. Tàbara. 2008. The growing importance of social learning in water resources management and sustainability science. Ecology and Society 13(1):24 http://dx.doi. org/10.5751/es-02352-130124

Pahl-Wostl, C., J. Sendzimir, P. Jeffrey, J. Aerts, G. Berkamp, and K. Cross. 2007. Managing change toward adaptive water management through social learning. Ecology and Society 12 (2):30. http://dx.doi.org/10.5751/es-02147-120230
Paschen, J.-A., and R. Ison. 2014. Narrative research in climate change adaptation: exploring a complementary paradigm for research and governance. Research Policy 43:1083-1092. http:// dx.doi.org/10.1016/j.respol.2013.12.006

Phillips, D. C., and N. C. Burbules. 2000. Postpositivism and educational research. Rowman and Littlefield, New York, New York, USA.

Primary Agency. 2016. Report on the community and stakeholder engagement for the $G-M W$ connections project reset. Primary Agency, East Melbourne, Victoria, Australia. [online] URL: http://www.connectionsproject.com.au/wp-content/uploads/2016/09/ Report-PrimaryAgency.pdf

Resilience Alliance. 2010. Assessing resilience in social-ecological systems: workbook for practitioners. Version 2.0. Resilience Alliance. [online] URL: http://www.resalliance.org/files/ ResilienceAssessmentV2 2.pdf

Rickards, L., and S. M. Howden. 2012. Transformational adaptation: agriculture and climate change. Crop and Pasture Science 63:240-250. http://dx.doi.org/10.1071/CP11172

Rickards, L., R. Ison, H. Fünfgeld, and J. Wiseman. 2014. Opening and closing the future: climate change, adaptation, and scenario planning. Environment and Planning C: Government and Policy 32:587-602. http://dx.doi.org/10.1068/c3204ed

Rijke, J., R. Brown, C. Zevenbergen, R. Ashley, M. Farrelly, P. Morison, and S. van Herk. 2012. Fit-for-purpose governance: a framework to make adaptive governance operational. Environmental Science and Policy 22:73-84. http://dx.doi. org/10.1016/j.envsci.2012.06.010

RMCG. 2016. Basin plan-GMID socio-economic impact assessment: final report. GMID Water Leadership Forum. RMCG, Bendigo, Victoria, Australia. [online] URL: http://www. rmcg.com.au/app/uploads/2017/01/Basin-Plan-Impact-GMID_Final_14October-2016.pdf

Rural Innovation Research Group. 2013. Workbook for assessing change challenges in dairy regions. Rural Innovation Research Group, University of Melbourne, Melbourne, Victoria, Australia, and Dairy Australia, Southbank, Victoria, Australia. [online] URL: http://rirg.fvas.unimelb.edu.au/ data/assets/ pdf file/0003/2247168/AssessingChangeChallengesinDairyRegionsWorkbook.pdf

Rydin, Y., and M. Pennington. 2000. Public participation and local environmental planning: the collective action problem and the potential of social capital. Local Environment 5:153-169. http://dx.doi.org/10.1080/13549830050009328

Schon, D. A. 1984. The reflective practitioner: how professionals think in action. Volume 5126. Basic Books, New York, New York, USA.

Sellberg, M. M., C. Wilkinson, and G. D. Peterson. 2015. Resilience assessment: a useful approach to navigate urban sustainability challenges. Ecology and Society 20(1):43. http://dx. doi.org/10.5751/es-07258-200143

Shapin, S., and S. Schaffer. 1985. Leviathan and the air pump: Hobbes, Boyle and the experimental life. Princeton University Press, Princeton, New Jersey, USA. 
Shove, E., and G. Walker. 2010. Governing transitions in the sustainability of everyday life. Research Policy 39:471-476. http:// dx.doi.org/10.1016/j.respol.2010.01.019

Sinclair, K., A. Curtis, E. Mendham, and M. Mitchell. 2014. Can resilience thinking provide useful insights for those examining efforts to transform contemporary agriculture? Agriculture and Human Values 31:371-384. http://dx.doi.org/10.1007/s10460-014-9488-4

Smit, B., and J. Wandel. 2006. Adaptation, adaptive capacity and vulnerability. Global Environmental Change 16:282-292. http://dx. doi.org/10.1016/j.gloenvcha.2006.03.008

Snyder, W. M., and E. Wenger. 2004. Our world as a learning system: a communities-of-practice approach. Pages 35-58 in $\mathrm{M}$. L. Conner and J. G. Clawson, editors. Creating a learning culture: strategy, technology and practice. Cambridge University Press, Cambridge, UK. http://dx.doi.org/10.1017/cbo9781139165303.004

Star, S. L., and J. R. Greismer. 1989. Institutional ecology, 'translations' and boundary objects: amateurs and professionals in Berkeley's Museum of Vertebrate Zoology, 1907-39. Social Studies of Science 19:387-420. http://dx.doi.org/10.1177/030631289019003001

Stoker, G. 1998. Governance as theory: five propositions. International Social Science Journal 50:17-28. http://dx.doi. org/10.1111/1468-2451.00106

Stone-Jovicich, S. 2015. Probing the interfaces between the social sciences and social-ecological resilience: insights from integrative and hybrid perspectives in the social sciences. Ecology and Society 20(2):25. http://dx.doi.org/10.5751/es-07347-200225

Tyre, M. J., and E. von Hippel. 1997. The situated nature of adaptive learning in organisations. Organization Science 8:71-83. http://dx.doi.org/10.1287/orsc.8.1.71

Wagenaar, H., and C. Wilkinson. 2013. Enacting resilience: a performative account of governing for urban resilience. Urban Studies 52(7):1265-1284. http://dx.doi.org/10.1177/0042098013505655

Walker, B. H., N. Abel, J. M. Anderies, and P. Ryan. 2009. Resilience, adaptability, and transformability in the GoulburnBroken Catchment, Australia. Ecology and Society 14(1):12. http://dx.doi.org/10.5751/es-02824-140112

Walker, B. H., L. H. Gunderson, A. P. Kinzig, C. Folke, S. R. Carpenter, and L. Schutlz. 2006. A handful of heurestics and some propositions for understanding resilience in socialecological systems. Ecology and Society 11(1):13. [online] URL: http://www.ecologyandsociety.org/vol11/iss1/art13/

Walker, B. H., C. S. Holling, S. R. Carpenter, and A. P. Kinzig. 2004. Resilience, adaptability and transformability in socialecological systems. Ecology and Society 9(2):5. http://dx.doi. org/10.5751/es-00650-090205

Walker, B., and D. Salt. 2012b. Resilience practice: building capacity to absorb disturbance and maintain function. Island, Washington, D.C., USA.

Walker, B., and D. Salt. 2012a. Resilience thinking: sustaining ecosystems and people in a changing world. Island, Washington, D.C., USA.
Wallis, P. J., B. L. Iaquinto, R. L. Ison, and R. J. Wrigley. 2014. Governing irrigation renewal in rural Australia. International Journal of Water Governance 2:19-36.

Wardekker, J. A., A. de Jong, J. M. Knoop, and J. P. van der Sluijs. 2010. Operationalising a resilience approach to adapting an urban delta to uncertain climate changes. Technological Forecasting and Social Change 77:987-998. http://dx.doi.org/10.1016/j. techfore.2009.11.005

Wenger, E. 1998. Communities of practice: learning, meaning and identity. Cambridge University Press, Cambridge, UK. http://dx. doi.org/10.1017/cbo9780511803932

Wenger, E. 2000. Communities of practice and social learning systems. Organization 7(2):225-246. 
Appendix 1. Interview questions for members of the communities of practice in irrigated dairying in the Goulburn-Broken Irrigation District, Australia.

1. What are the main challenges for you in managing your dairy businesses over the next 5 years? (Prompt: Please talk from your perspective.)

2. Are these challenges the same for other dairy farmers you know? Do other farmers you know say different things about their farming future? (Prompt: Why do you think this is the case?)

3. Thinking about the farmers and the dairy companies in this (Murray Dairy) region... have the challenges for the dairy industry been covered by what you've said or are there other challenges for this region?

4. What has helped you to manage your dairy businesses through the recent period of water management and policy changes in the Goulburn Murray Irrigation District and across the Murray Darling Basin more broadly? (over the past 5 years)

5. Can you please talk about how your local community has helped you to address these challenges (related to water management and policy changes) you have faced? How has the dairy industry helped you address these challenges? Are there others who have also been important in addressing these challenges? (Prompts: Who has been involved? How have they worked together? What was involved?)

6. Assuming there will be less irrigation water available in the future due to a combination of factors, e.g. competing interests for environmental flows (water policy change), growing urban populations, climate change, bushfires etc., can you please describe the (two) most important things that will help you in your dairy businesses to deal with changes in irrigation water availability?

7. What could be improved with respect to water management and policy and dairying in this region? And: How could these improvements be made? Who would need to be involved? What would need to happen? 